This item was submitted to Loughborough's Research Repository by the author.

Items in Figshare are protected by copyright, with all rights reserved, unless otherwise indicated.

\title{
You must be joking: the sociological critique of humour and comic media
}

PLEASE CITE THE PUBLISHED VERSION

http://dx.doi.org/10.1111/j.1751-9020.2008.00108.x

\section{PUBLISHER}

() Blackwell Publishing Ltd

\section{VERSION}

SMUR (Submitted Manuscript Under Review)

\section{LICENCE}

CC BY-NC-ND 4.0

\section{REPOSITORY RECORD}

Lockyer, Suzanne, and Michael Pickering. 2019. "You Must Be Joking: The Sociological Critique of Humour and Comic Media". figshare. https://hdl.handle.net/2134/5599. 
This item was submitted to Loughborough's Institutional Repository (https://dspace.lboro.ac.uk/) by the author and is made available under the following Creative Commons Licence conditions.

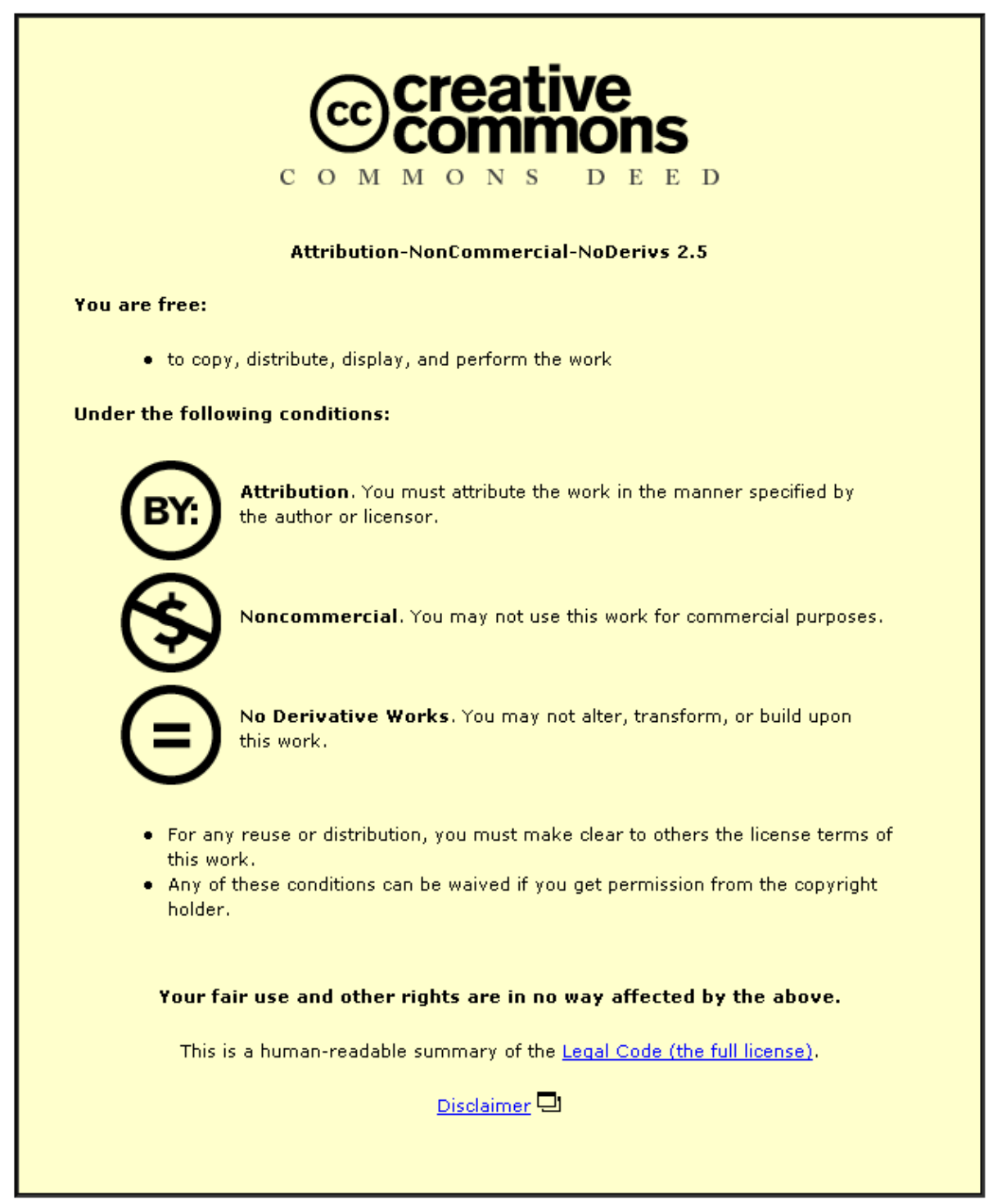

For the full text of this licence, please go to: http://creativecommons.org/licenses/by-nc-nd/2.5/ 


\title{
You Must Be Joking: \\ The Sociological Critique of Humour and Comic Media
}

Sharon Lockyer and Michael Pickering

\author{
Sharon Lockyer \\ Lecturer in Sociology and Communications \\ School of Social Sciences \\ Brunel University \\ Uxbridge \\ Middlesex \\ UB8 3PH, UK \\ Email: Sharon.Lockyer@brunel.ac.uk \\ Michael Pickering \\ Professor of Media and Cultural Analysis \\ Department of Social Sciences \\ Loughborough University \\ Loughborough \\ Leicestershire \\ LE11 3TU, UK \\ Email: m.j.pickering@lboro.ac.uk
}




\title{
You Must Be Joking: The Sociological Critique of Humour and Comic Media
}

\begin{abstract}
Recent work in the sociological critique of humour and comic media has challenged the notion that humour is an absolute good. In this article we review some of the most interesting work that takes humour seriously and addresses the difficult topic of whether there are ethical limits to humour and media comedy. We outline three main reasons for taking humour seriously and review some of the ways in which humour has been studied sociologically through a consideration of how British 'alternative' comedy directed the work of those interested in the limits of humour in relation to gender, race and ethnicity. We also summarise some of the most controversial examples of contemporary media comedy - the comedic performances and personae of Sacha Baron Cohen (Ali G and Borat) and the Danish cartoons of the Holy Prophet Muhammad - in order to illustrate the importance of the critical analysis of humour and how the ethics of humour can be applied to comic media.
\end{abstract}

\section{Introduction: Taking Humour Seriously}

Taking humour seriously seems a mistaken venture. The common assumption is that humour should not be taken seriously, for humour is an antidote to seriousness. It seeks to upset the proprieties of seriousness and prevent us from taking ourselves too seriously. The application of sociological perspectives to humour only seems to compound the mistake, so risking turning sociology itself into a laughing stock, or at least diverting it from such serious issues as the social configurations of division and distinction, or changing forms of sociality and social networks. To the objections that sociology should not stoop to such trivialities as jokes or joking relationships, and that humour is too inconsequential to be worth detailed investigation, we can add another. This is that laughter is beyond the reach of rational analysis and debate. To laugh is to transcend the whole point and purpose of being analytical. Best, then, to keep humour and social analysis firmly apart.

The most interesting and valuable work that has recently been accomplished in the sociology of humour refutes these assumptions and objections. Our purpose in this article is to review this work and its more specific focus on controversial examples of media comedy. We identify the key issues and themes it addresses, and argue that its major critical point is the need to challenge the contemporary notion of humour as an absolute good, as a necessary and vital attribute of being human . To begin with, we want to outline three good reasons why humour should be taken seriously and why its sociological critique has to negotiate the question of whether there are valid ethical limits to humour. We shall then elaborate on these in discussing various examples of critical sociological work on humour and media comedy. In doing so we operate with a working distinction which takes comedy as usually involving scripted or formalised versions of comic discourse and conduct for stage and screen, and humour as the much broader phenomena of talk or behaviour in everyday life which is the source of, or catalyst for, amusement, laughter and the joking relationship itself.

First, humour is far from trivial. It is integral to social relationships and social interaction. It may be taken in certain contexts as light-hearted banter, but in other contexts it can injure people's social standing, or cut deeply into relationships and interaction between people within and across different social groups. Added to this is another critical point: if humour is a relatively trivial affair, how can it also be regarded as transcendent and so exceeding the scope of rational analysis and debate? To see it in both ways is a contradiction in terms, and it is not a spurious one. It arises because humour is not being taken seriously enough, or because it takes itself too seriously. On both counts it supports the case for a critical analysis of humour. Second, humour is not set diametrically in opposition to seriousness, not least because it can have serious implications and repercussions. Some forms of humour, as for example those involving sexist assumptions about gender roles and identities, are far from inconsequential. Third, to take humour seriously is not being anti-humour. It is not intended to stop people laughing. It is to say instead that in its various communicative acts humour forms a distinct modality of human interaction, universal in occurrence yet highly particular in how it operates and how it is is sanctioned within different societies and 
different historical periods. What is found funny, and why, is spatially and temporally specific. Trying to understand this can tell us much about social identities and values in space and across space, and in time and over time. The sociological analysis of humour can tell us much about how existing social relations are reaffirmed and normative social boundaries maintained.

There are of course occasions when humour seems almost anarchic in its disrespect for established structures or cherished values, but as Mary Douglas (1968: 366) famously pointed out, successful jokes must be recognised as such and socially permitted, at least by more than one participant. The same principle applies to humour more generally. In a study of humour that is predicated on its serious sociological analysis, Jerry Palmer asks what happens when jokes fail, or are not given institutional sanction. The question takes us beyond the formal consideration of comic discourse, and does so because the success or failure of humour depends upon how it corresponds to the appropriateness of the social occasion and circumstances in which it occurs. Humour is never exclusively derived from its cultural forms or from its prescriptive functions, for it has also to be regarded as appropriate to its occasioned performance and the ways in which such performance relate to a broader social order. Both the teller and the recipients of humour are implicated in whether it works or falls flat on its unfunny face. Their social identities and relations, as well as the occasions and settings in which they are placed, have at least tacitly to be understood for any appreciation of why comic meaning is successful or not. All jokes are, in a sense, injokes and we need to be at least partially in-the-know in order to have any evaluative sense of them. Examining the limits of humour does not mean a denial of comic structure but rather, as Palmer points out, negotiation of that structure in relation to the principles of comprehensibility, performative adequacy and inoffensiveness. For Palmer, an attempt at humour is likely to be found offensive according to three main variables, which may figure in any combination in individual circumstances: the structure of the joke, considered as a representation of the world external to the joke; the relationship between the joke-teller and the others involved in its accomplishment - the butt and the audience; and the nature of the occasion on which the attempt at humour is made (Palmer, 1994: chapter 13; see also Palmer, 1987).

\section{Politics of Alternative Comedy}

Those who have investigated the question of comic failure and the limits of humour were at least to some extent directed towards this as a result of the anti-sexist, anti-racist shifts that distinguished British 'alternative' comedy in the 1980s (Pickering and Littlewood, 1998; see also Cook, 1994, Wagg, 1996, Double, 1997: chapter 8). This branch of comedy developed from the late 1970s in reaction to the comic acts and routines of mainstream media and showbiz comedy. By the 1970s the offensive comedy rife in working men's clubs and similar entertainment milieux had filtered through in diluted form to television and radio. Such comedy was nevertheless replete with racist and sexist stereotypes. With 'alternative' comedy, jokes of the 'jungle bunny', 'thick Mick', 'Essex girl’, 'mother-in-law’ kind were out; send-up forms of self-narrative and social realism with a satirical edge were in. Packaged gags and tired catchphrases were swept away by comic onslaughts against Thatcherism, middle-class foibles and male hypocrisies, and feminist or feminist-aware comedians began at last to gain a foothold on the comedy circuit. A lovely example of this was Jo Brand's turning of the comic table on men: 'The way to a man's heart is through his hanky pocket with a bread knife'. Such shifts led to greater ethical awareness on the part of both comedians and their audiences, and to some extent a backlash in defence of comedy based on racial and gender stereotypes or gratuitous obscenity. In the main, the politics of 'alt com' were liberal or libertarian rather than leftwing or directly oppositional to mainstream values and practices, but at its best 'alternative' comedy seemed to say what it meant and mean what it said, in a new, values-on-its-sleeve approach.

Since the 1980s, the increased attention paid to the need for thinking self-reflexively about the social implications of comic representations has been conducive to research and writing focused on the ethics of humour. Various studies have looked specifically at the politics of gender in comedy while also reclaiming a female comic tradition (see Banks and Swift, 1987; Barreca, 1988; Finney, 1994; Gray, 1994; Sochen, 1994; Cotterill, 1996; Oddey, 1999; and various examples in Wagg, 1998). Racism in humour has also remained a major topic. In both cases the question of comic failure is paramount, for when a joke is critically evaluated as sexist or racist, by definition the joke fails and becomes severely devalued as comic 
discourse. Why humour is sometimes found offensive, what social functions offensive humour performs, and how the ethical limits of humour can be negotiated are the sort of questions raised by its failure. This is particularly the case with racism in humour. Racist humour is a form of comic malice, but like any form of humour, it involves both ethics and aesthetics. There is on the one hand a need to appreciate how humour not only permits but can also legitimate and exonerate a racist insult. The sociological critique of humour and negotiation of its ethical limits remains stunted without a detailed examination of the linguistic structures and situational dynamics of racism as it is comically manifest. On the other hand, the ethics of humour necessitate attention to the difficult relationship between free expression and moral censure. They cannot be confined to a right to offend.

\section{The Right to Offend}

In the view of the British comedian, Rowan Atkinson, 'the right to offend is far more important than any right not to be offended' (The Guardian, 7 December 2004). Clearly, opposing racism is not synonymous with abolishing anyone's right to offend or right to freedom of speech more generally, but at the same time liberal tolerance is not synonymous with the acceptance of public expressions of racist bigotry or hatred comic or otherwise - since such bigotry or hatred itself stands counter to liberal values. By extension, questioning comic offensiveness is not equivalent to illiberal moralism. These points apply to racist humour just as they do to any communicative act, but what has to be recognised in the case of comic discourse is that 'it is precisely the symbolic separation from the realm of serious action that enables social actors to use humour for serious purposes' (Mulkay, 1988: 1). Anyone studying humour needs a sharp ear for the ambiguities and polysemia that are integral to its specific semantic domain and the ways in which it operates discursively. They have also to be attentive to the ways in which humour provides a licence to be offensive, racially or otherwise. As a result of this, 'only joking' is the classic let-out clause when a racist joke falls on unreceptive ears or when a gag with racist implications seriously backfires. The excuse assumes that a joke is just a joke and cannot be taken seriously. This is exactly the rhetorical effectiveness upon which offensive comic discourse relies. The consequence is our difficulty in objecting when humour is regarded as overstepping the mark and causing offence. Other rhetorical devices become necessary. Complaints against offensive humour often use forks of linguistic framing to offset potential objections to what is said, with attempts to protect the complainant from accusations of being humourless also working to augment the power of the complaint: for example, the typical opening clause 'I have a sense of humour but ...' creates an initial endorsement for a subsequent, semantically divergent objection to what has been experienced as comically offensive. The strategy is an attempt to navigate the treacherous waters between ethical issues and comic discourse (see Lockyer and Pickering, 2001 for a case study of the strategy). Such double-handed manoeuvres signal recognition of the tensions that arise between the 'right to offend' and the rightful articulation of objections to comic misprision and the joking vehicles of stereotyping, particularly as the so-called humour in these cases can act to camouflage or deflect attention from the stereotyping (see Pickering, 2001 for a sociological critique of stereotyping).

Over the past twenty years or so offensive jokes made by stand-up comedians, politicians and media pundits have received intense coverage in the press and on radio and television. Despite this public attention, quite what is involved in thinking about the ethical limits of humour has stood in need of fuller discussion and debate. A recent contribution to such debate brought together some of the key sociological writers on humour (Lockyer and Pickering, 2005). This book is dedicated to exploring in detail the tensions between serious and comic discourse, and more specifically between humour and offensiveness. It is especially attentive to how comic offensiveness relates to social divisions and inequalities, and structures of power in society. Blatant examples of racism in humour are critically treated. These range from violent racist jokes on Ku Klux Klan websites through Silvio Berlusconi’s Nazi gaffe in the European parliament and Ann Winterton's Chinese cocklepicker joke to more ambiguous comic forms involving ethnic impersonation and comedic uses of embarrassment. The blurred lines between 'mockumentaries' and mockery, and between affirmation and derogation in dramatic personae, are also subject to analysis. If there is a 'right to offend', what remains crucial is whether the humour kicks socially up or down, whether comic aggression is directed 'at those who are in positions of power and authority, or at those who are relatively powerless and subordinated' (Pickering and Littlewood, 1998: 295). The new self-consciousness about the relations of laughter and power in social life has heightened awareness of the significant differences between satirical assault on venal politicians and capitalists, and the comic ridicule of those already 
oppressed and socially marginalized. While the primary focus in recent critical work has been on racism and humour, attention is now turning to comic representations of social class, though again asking the same question: does the humour ridicule and mock those in privileged and powerful social positions, or those in vulnerable or deprived positions, such as single parents, the homeless or those on welfare (see Lockyer, 2009).

Specifically racist forms of humour and the rhetorical techniques through which they operate have been extensively studied by Simon Weaver (2007). Weaver charts the shift from biological racism and embodied racist humour to the more recent coded forms of cultural racism, as well as dealing with attempts by ethnic minorities to resist and reverse racism in comic discourse. He draws particularly on Zygmunt Bauman's treatment of the move from modernity to postmodernity, and uses his concept of liquid modernity in relation to the fluid and complex ambivalences of racist semantics in contemporary media comedy. What Weaver calls liquid racism (racism which is elusive because masked in irony) makes the task of sociological critique harder but no less imperative than in relation to its earlier, cruder forms and their comic expression. While such forms continue to exist (see e.g. Billig, 2001; Howitt and OwusuBempah, 2005), they are not as rooted in order-building processes as they were in the period of high modernity and imperialism (for these, see Pickering, 2001). Race thinking and racial discourse were closely associated with humour during that period. This has been particularly well highlighted in the historical work that has been done on humour and comedy. Key examples are American and British studies of blackface minstrelsy, a transatlantic cultural form which subjected black people to sentimental and comic stereotypes, and studies of the mediation of empire, race and nationhood on the popular stage (see e.g. Toll, 1974; Bratton et al, 1991; Lott, 1993; Platt, 2004; Pickering, 2008). Those construed as racially inferior were those constructed as figures of fun and comic derision.

Humour and comedy can easily descend into ridicule and mockery. Who has been chosen as the comic targets of ridicule and mockery and what lies behind these choices need to be seriously investigated if we are to move towards a more sensitive ethical consideration of cultural representations in public forms of humour. Just as importantly, we need to question whether humour itself is necessarily and unambiguously good. As its sociological critique has now made abundantly clear, comic discourse and narrative can have pernicious implications and consequences, yet bringing these into serious analytical focus always runs the risk of seeming po-faced and stereotypically donnish. This will always remain the case when humour itself is regarded as an intrinsically positive dimension of social life. The view that it is lies enshrined in such popular sayings as 'better to laugh than cry' and in common-sense advice encouraging us to 'see the funny side' of things. It is also advanced in some of the most celebrated scholarly writings on humour. Michael Billig (2005) has subjected one-dimensional positive evaluations of humour to thoroughgoing critique in his book Laughter and Ridicule. The title reflects his contention that ridicule is not an aberrant feature of humour, but central to it and the aggression which it masks. The key point of the book is that ridicule itself, along with its comic vehicles, resides 'at the core of social life, for the possibility of ridicule ensures that members of society routinely comply with the customs and habits of their social milieu' (p. 2). This imparts to humour a key role in social discipline and the maintenance of social order.

Billig concentrates largely on theoretical claims that humour is invariably beneficial rather than on the analysis of media comedy. This has the virtue of showing that current eliminations of the negatives of humour have not been present in other historical periods. His critique also has various implications for future work that takes comic offensiveness seriously and tries to develop and apply an ethics of humour to comic media. Such applications would test whether Billig has over-emphasised ridicule as a powerful but not all-pervasive feature of humour, and whether all forms of comic media inevitably carry a downside. Is it always a case of laugh and repress, joke and discipline? What does this say of the laughter of the oppressed? If media and cultural analysts want to ensure that such laughter is not lost in the critical distance, they will need to learn how to square an ethics of humour with the aesthetics of comic ambivalence. 


\section{Battle of Baron Cohen}

In recent years, questionable examples of media comedy and jokes told in public settings by politicians and celebrities have increasingly become the object of critical attention, especially after being reported and discussed in the press. Jokes and joking performances that are perceived by some as moving into the realm of offensiveness have ignited academic and media-based debates regarding the intentions of humour makers, comedy's potential to challenge taboos, and the limits of free speech and expression. Jokes, cartoons, spoof interviews and mockumentaries about a range of topics from race and ethnicity to religion and terrorism, have been key issues in these debates.

One contemporary performer who has received considerable critical attention is the British comedian, Sacha Baron Cohen (Malik, 2002; Lockyer and Pickering, 2005; Howells, 2006; Saunders, 2007). Two of Baron Cohen's fictitious characters - Ali G, a wannabe gangsta rapper from the South East of England, and Borat, a Kazakhstani television reporter - have been at the centre of the controversies that together constitute the 'Battle of Baron Cohen'. Although Ali G has been immensely popular among some British and American film and television viewers, he has not only been criticised for his homophobic and misogynistic outlook, but also opposed by black comedians for pandering to racist stereotypes. Others have objected to the intense media exposure given to him, on the grounds that this would not have been given to a black comedian (see Malik, 2002; Howells, 2006). The controversy surrounding this popular comedy icon was in many ways generated by the complex layering of his persona where an educated white Jewish comedian acts out the street style of an uneducated Black-British 'yoof'. The key issues have revolved around the question of who was impersonating whom in the Ali G persona and whether this subverted or perpetuated the possibilities of black stereotyping. Was Ali G a white, Jewish or Asian wannabe? Alternatively, was he a white man pretending to be an Asian pretending to be black, or a Jewish man pretending to be an Asian pretending to be a white man pretending to be black? Perhaps he was something entirely different to any of these, such is the difficulty of identifying him (Malik, 2002; Lockyer and Pickering, 2005; Howells, 2006). The difficulty of identification surrounding Baron Cohen and his Ali $G$ persona suggests that audiences have been laughing for different, and often contradictory, reasons. Such responses could be read as a contemporary version of what has been termed the 'Alf Garnett Syndrome' (Lockyer and Pickering, 2005), where anti-racist critique is misinterpreted as racist celebration. It can be argued that Sacha Baron Cohen 'gets away' with his racist, homophobic and misogynist jokes, with condoning drug use and car crime, and with being obsessed by designer labels and the size of his penis due to three features of his performance: 1 ) the (mis)use of comic impersonation, which extends the ethical limits to permit offence, and distances Baron Cohen from criticism and hostility (Howells, 2006; Lockyer and Pickering, 2005); 2) his use of the 'humour of transgression', where humour is generated by transgressing the boundaries of acceptable behaviour so that it is not necessarily created by the content of Ali G's speech, but by the inappropriateness of saying certain things in certain situations; and 3) resisting requests for interviews, so avoiding the need to be explicit or provide explanations about who Ali $G$ is or what he is trying to say or achieve through his performances. To some extent these conditions apply also to Baron Cohen's other comic persona, Borat Sagdiyev.

Although his media identity as a Kazakhstani television reporter is less ambiguous that the Ali G persona, Borat met with an intensely hostile reaction from the Kazakhstani government following his appearances on the MTV Europe Music Awards in 2005, and (in global box office terms) the highly successful film, Borat: Cultural Learning of America for Make Benefit Glorious Nation of Kazakhstan (2006). In this film we follow Borat as he travels across the United States. Through globally-linked mass-media Borat mocks Kazakhstan and its post-soviet culture at a time when, since gaining independence in 1991, the country is preoccupied by the question of its national identity. The Kazakhstani government, sensitive about the negative portrayal of Kazakhstani culture and character, closed down Borat's website, borat.kz, and threatened legal action. Concerns resonate around Borat's representations of the extra-European Other, or more specifically, the contrast between developed and undeveloped countries, the gratuitous cruelty of his comic ridicule, and in the Borat film, his avowed anti-Semitism (Muravchik, 2007). In the conclusion to his analysis of the Borat phenomenon in the global marketplace, Saunders writes:

Baron Cohen's subreption of Kazakshilik [Kazakhness] is therefore more than just a joke - it is an alternative narrative told at the global level through transnational, deterritorialized media. As a 
result of the weaknesses of Kazakhstani national identity and the country's keen desire to present an attractive brand to the global marketplaces, the Borat phenomenon is especially unwelcome at this particular juncture. Nazarbayev and the political elites he controls realize their role as arbitrageurs of the nation - a nation which has been wounded by Baron Cohen (2007: 249)

Opinion seems to have shifted since the Borat controversy in 2005. The president's daughter, Dariga Nazarbayeva, now avers that the closure of the Borat web site was more damaging than the website itself. Disregarding the rights or wrongs of the responses of the Kazakh authorities, the Borat controversy, and the debates around Ali G, are socially significant due to the way in which they illustrate the complexity of the issues surrounding the interacting coordinates of racism and ethnic identity, comic performance and intent, and the context of audience reception and understanding.

\section{Danish Cartoon Crisis}

Another contemporary controversy over media comedy that has severely tested the ethical limits of comic representations manifest at local, national and international levels is the furore over the depiction of the Holy Prophet Mohammad in twelve satirical cartoons published in the Danish newspaper Jyllands-Posten in September 2005 (Hervik, 2006; Ammitzbøll and Vidino, 2007; Codina and Rodríguez-Virgili, 2007; Kunelius et al, 2007; Müller and Özcan, 2007). Through stylistic conventions that include exaggeration, ridicule and distortion (Müller and Özcan, 2007), cartoons have a form that 'helps create a subversive way of understanding the world' (Maggio, 2007: 238). Published under the title 'Faces of Muhammad', the cartoons made liberal use of these conventions, as for example in depicting the Prophet wearing a bombshaped turban with a lighted fuse. According to Codina and Rodríguez-Virgili, their publication was a 'strategy to challenge moderate European Muslims to speak out on the social consequences of some radical Islamist standpoints’ (2007: 32). This was in a socio-cultural context where, since the early 1990s, neonationalism and neo-racism have become once again ascendant and where the rise of the anti-immigrant Danish People's Party (DPP) has negatively targeted and stereotyped the Muslim minority (Hervik, 2006; see also Müller and Özcan, 2007)

Publication of the cartoons outraged members of the Danish Muslim community and the wider international Muslim community, and their anger was reinforced by the refusal of the Prime Minster, Andres Fogh Rasmussen, to meet with ambassadors representing Muslims and the Islamic faith. Readers' letters of complaint were sent to the newspaper at the centre of the storm; a number of transnational protests and riots occurred, some peaceful, others involving the torching of Danish embassies in Beirut and Damascus and resulting in a total of 130 deaths related in some way to the violence (Kunelius and Eide, 2007); fatwas were issued appealing for the death of the cartoonists; Danish products were boycotted by Muslims; and some of those demonstrating against the cartoons in the UK have been convicted of soliciting to murder after telling a demonstrating crowd to bomb the UK and for stirring up racial hatred during the cartoon protests. The unprecedented row over the cartoons has been described as 'the most serious crisis in Danish foreign policy since the Second World War' (Hervik, 2006: 225) and as 'arguably the second major event after the September 11, 2001, terrorist attacks that brought "Muslims” as a group of political actors to the forefront of international politics' (Müller and Özcan, 2007: 287). The cartoons and the subsequent row can be explained by the racial biases within Danish society and fears over Islam fundamentalist terrorism on the one hand and, on the other, from a Danish Muslim perspective, the reinforcement of stereotypes of the Danish in their disrespect of Islamic religious beliefs and their regard of all Muslims as terrorists (Müller and Özcan, 2007).

\section{Conclusion}

Challenging the notion of humour as an absolute good means that humour cannot be taken as a form of discourse or performance that is isolated from other discourses or from wider configurations of sociality and social relations. Humour may at times provide distraction or diversion from the serious sides of life or from entrenched social problems, but it is not separate or separable from the broad spectrum of communicative forms and processes or from the manifold issues surrounding social encounter and interaction in a multicultural society. Sexism, racism, homophobia and other kinds of prejudice and bigotry are not exonerated by their appearance in comic discourse; indeed, they may be more effectively 
communicated, disseminated and reinforced by being articulated under the wraps of humour and comedy. Critical humour studies not only addresses the relations between comic and other forms of discourse and rhetoric, but also focuses on what is specific to jokes and joking relationships and what makes humour and comic genres distinctive as modes of communication and representation. Most importantly, this emergent field of study recognises the centrality of comic media in contemporary western cultures, and on this basis investigates the interface between humour and ethics. The relationship between them is mutable and always shifting, and so always up for negotiation and renegotiation. How, when, where, by whom and on what terms this is undertaken are among the most pressing questions we face in trying to understand humour and comic media sociologically.

\section{References}

Ammitzbøll, Pernille and Lorenzo Vidino 2007. “After the Danish Cartoon Controversy.” Middle East Quarterly, 14: 3-11.

Banks, Morwenna and Amanda Swift 1987. The Joke's On Us: Women in Comedy from Music Hall to the Present Day. London: Pandora.

Barreca, Regina ed. 1988. Last Laughs: Perspectives on Women and Comedy. Reading and New York: Gordon and Breach.

Billig, Michael 2001. "Humour and Hatred: The Racist Jokes of the Ku Klux Klan.” Discourse and Society 12: 267-89.

Billig, Michael 2005. Laughter and Ridicule: Towards a Social Critique of Humour. London and Thousand Oaks: Sage.

Bratton, Jacqueline S, Richard A Cave, Brendan Gregory, Heidi J Holder and Michael Pickering 1991. Acts of Supremacy: The British Empire and the Stage, 1790-1930. Manchester and New York: Manchester University Press.

Codina, Mónica and Jordi Rodríguez-Virgili 2007. “Journalism for Integration: The Muhammad Cartoons.” Javnost, 14: 31-46.

Cook, William 1994. Ha Bloody Ha: Comedians Talking. London: Fourth Estate.

Cotterill, Pamela 1996. “'It’s Only a Joke’: the Role of Humour in Mother-in-Law Relationships.” Pp. 193217 in The Social Faces of Humour: Practices and Issues, edited by George Paton, Chris Powell and Stephen Wagg. Aldershot: Arena/Ashgate.

Double, Oliver 1997. Stand-Up: On Being a Comedian. London: Methuen.

Douglas, Mary 1968. “The Social Control of Cognition: Some Factors in Joke Recognition.” Man n.s. 3: 361-76.

Finney, Gail ed. 1994. Look Who’s Laughing: Gender and Comedy. Reading and New York: Gordon and Breach.

Gray, Frances 1994. Women and Laughter. Basingstoke and London: Macmillan.

Hervik, Peter 2006. “The Predictable Responses to the Danish Cartoons.” Global Media and Communication, 2: 225-230.

Howells, Richard 2006. “'Is It Because I Is Black?’ Race, Humour and the Polysemiology of Ali G.” Historical Journal of Film, Radio and Television, 26: 155-77. 
Howitt, Dennis and Kwame Owusu-Bempah 2005. "Race and Ethnicity in Popular Humour.” Pp. 45-62 in Beyond A Joke: The Limits of Humour, edited by Sharon Lockyer and Michael Pickering. Basingstoke and New York: Palgrave Macmillan.

Kunelius, Risto and Elisabeth Eide 2007. “The Mohammed Cartoons, Journalism, Free Speech and Globalization.”. Pp. 9-23 in Reading the Mohammed Cartoons Controversy: An International Analysis of Press Discourses on Free Speech and Political Spin, edited by Risto Kunelius, Elisabeth Eide, Oliver Hahn and Roland Schroeder. Working Papers in International Journalism. Bochum/Freiburg Projectverlag.

Kunelius, Risto, Elisabeth Eide, Oliver Hahn and Roland Schroeder eds. 2007. Reading the Mohammed Cartoons Controversy: An International Analysis of Press Discourses on Free Speech and Political Spin. Working Papers in International Journalism. Bochum/Freiburg Projectverlag.

Lockyer, S. 2009 add title

Lockyer, Sharon and Michael Pickering 2001. "Dear Shit-shovellers: Humour, Censure and the Discourse of Complaint.” Discourse and Society, 12: 633-651.

Lockyer, Sharon and Michael Pickering eds. 2005. Beyond a Joke: The Limits of Humour. Basingstoke and New York: Palgrave Macmillan.

Lott, Eric 1993. Love and Theft: Blackface Minstrelsy and the American Working Class. New York and Oxford: Oxford University Press.

Maggio, J. 2007. “Comics and Cartoons: A Democratic Art-Form.” PS - Political Science and Politics, 40: 237-239.

Malik, Sarita 2002. Representing Black Britain: Black and Asian Images on Television. London: Sage.

Mulkay, Michael 1988. On Humour. Cambridge: Polity.

Müller, Marion G and Esra Özcan 2007. "The Political Iconography of Muhammad Cartoons:

Understanding Cultural Conflict and Political Action.” PS - Political Science and Politics, 40: 287-291.

Muravchik, J. 2007. “Borat!.” Commentary Magazine, 123: 44-47.

Oddey, Alison ed. 1999. Performing Women: Stand-Ups, Strumpets and Itinerants. Basingstoke and London: Macmillan.

Palmer, Jerry 1987. The Logic of the Absurd. London: British Film Institute.

Palmer, Jerry 1994. Taking Humour Seriously. London and New York: Routledge.

Pickering, Michael 2001. Stereotyping: The Politics of Representation. Basingstoke and New York: Palgrave Macmillan.

Pickering, Michael 2008. Blackface Minstrelsy in Britain. Aldershot UK and Burlington VT: Ashgate.

Pickering, Michael and Jane Littlewood 1998. "Heard the One About the White Middle Class Heterosexual Father-in-Law ? Gender, Ethnicity and Political Correctness in Comedy.” Pp 291-312 in Because I Tell a Joke or Two: Comedy, Politics and Social Difference, edited by Stephen Wagg. London and New York: Routledge.

Platt, Len 2004. Musical Comedy on the West End Stage, 1890-1939. Basingstoke and New York: Palgrave Macmillan. 
Saunders, Robert A. 2007. “In Defence of Kazakshilik: Kazakhstan’s War on Sacha Baron Cohen.” Identities: Global Studies in Culture and Power, 14: 225-255.

Sochen, June ed. 1991. Women’s Comic Visions. Detroit: Wayne State University Press.

Toll, Robert C. 1974. Blacking Up: The Minstrel Show in Nineteenth Century America. London and New York: Oxford University Press.

Wagg, Stephen 1996. "Everything Else is Propaganda: The Politics of Alternative Comedy.” Pp. 321-47 in The Social Faces of Humour: Practices and Issues, edited by George Paton., Chris Powell and Stephen Wagg. Aldershot: Arena/Ashgate.

Wagg, Stephen ed. 1998. Because I Tell A Joke or Two: Comedy, Politics and Social Difference. London and New York: Routledge.

Weaver, Simon 2007. Humour, Rhetoric and Racism: A Sociological Critique of Racist Humour. Unpublished PhD thesis, University of Bristol.

\section{Short Biography}

Sharon Lockyer is a Lecturer in Sociology and Communications in the School of Social Sciences at Brunel University, UK. Her research interests are in the sociology of mediated culture and critical humour studies. She is co-editor, with Michael Pickering, of Beyond a Joke: The Limits of Humour (2005) and has published in a variety of academic journals including Discourse and Society; Journalism Studies; International Journal of Social Research Methodology: Theory and Practice and Ethical Space. She holds a BSc and a PhD in Communication and Media Studies, both from Loughborough University, UK.

Michael Pickering is Professor of Media and Cultural Analysis in the Department of Social Sciences at Loughborough University, UK. He has published in the areas of cultural history and the sociology of culture as well as media analysis and theory. His recent books include History, Experience and Cultural Studies (1997); Researching Communications (1999/2007), co-written with David Deacon, Peter Golding and Graham Murdock; Stereotyping: The Politics of Representation (2001); Creativity, Communication and Cultural Value (2004), co-written with Keith Negus; Beyond a Joke: The Limits of Humour (2005), coedited with Sharon Lockyer; Blackface Minstrelsy in Britain (2008) and Research Methods for Cultural Studies (2008). 